\title{
BAGAIMANA ADAPTASI TATANAN KEBIASAAN BARU DAN KONDISI GIZI IBU HAMIL SELAMA PANDEMI COVID-19?
}

\author{
Widya Wati ${ }^{1}$, Wiwin Efrizal ${ }^{2}$ \\ Puskesmas Sungailiat Kabupaten Bangka ${ }^{l}$ \\ Dinas Kesehatan Provinsi Kepulauan Bangka Belitung ${ }^{2}$ \\ e-mail: ${ }^{1}$ widyawatihafiza07@gmail.com, ${ }^{2}$ wiwinefrizal@gmail.com
}

\begin{abstract}
Pregnant women are one of the vulnerable groups in the transmission of Covid-19, although most do not show symptoms when exposed. The application of the Adaptation of the New Habit Order is carried out to avoid transmission. The purpose of this study was to determine the application of the adaptation of a new habit order to pregnant women in Sungailiat District and the nutritional condition of the mother during the Covid-19 pandemic using a descriptive correlative method with a cross-sectional design. It was found that most of the respondents had implemented the use of masks, washed their hands with soap and kept their distance, but only $17.6 \%$ avoided crowds. The difference in health services was felt by $41 \%$ of respondents who thought it was not easy to get health services, because they had to implement health protocols. Consumption of main meals on a regular basis is carried out by $85 \%$ of respondents, but only $35 \%$ of respondents consume snacks. Chronic energy deficiency (KEK) occurred in $8.8 \%$ of respondents and anemia was experienced by $20.6 \%$ of respondents. The conclusion obtained is that most of the respondents have adapted the new habit order and the general nutritional condition is quite good, although attention needs to be paid to the occurrence of cases of KEK in pregnant women Write your abstract in English, without indentation. Write methods and results in pastense. Write your abstract in one paragraph.
\end{abstract}

Keywords: covid-19; pregnancy; behavior

\begin{abstract}
ABSTRAK
Ibu hamil merupakan salah satu kelompok rawan dalam penularan Covid-19, meskipun sebagian besar tidak menunjukkan gejala pada saat terpapar. Penerapan Adaptasi Tatanan Kebiasaan Baru dilakukan untuk menghindari terjadinya penularan. Tujuan penelitian ini adalah diketahuinya penerapan adaptasi tatanan kebiasaan baru pada ibu hamil di Kecamatan Sungailiat dan kondisi gizi ibu selama Pandemi Covid-19 menggunakan metode deskriptif korelatif dengan desain potong lintang. Ditemukan bahwa sebagian besar responden telah menerapkan penggunaan masker, cuci tangan pakai sabun dan menjaga jarak, namun hanya 17,6\% yang menghindari kerumunan. Adanya perbedaan dalam pelayanan kesehatan dirasakan oleh $41 \%$ responden yang beranggapan tidak leluasanya mendapatkan pelayanan kesehatan, karena harus menerapkan protokol kesehatan. Konsumsi makanan utama secara teratur dilakukan oleh $85 \%$ responden, namun hanya $35 \%$ responden yang mengkonsumsi makanan selingan. Kekurangan energi kronik (KEK) terjadi pada 8,8\% responden dan anemia dialami oleh 20,6\% responden. Kesimpulan yang diperoleh adalah adaptasi tatanan kebiasaan baru telah dilakukan sebagian besar responden dan kondisi gizi secara umum telah cukup baik, meskipun perlu diberikan perhatian pada terjadinya kasus KEK pada ibu hamil.
\end{abstract}

Kata kunci: covid-19; kehamilan; perilaku 


\section{PENDAHULUAN}

Infeksi virus Coronavirus 2 (SARS-CoV-2) yang menyebabkan penyakit Coronavirus 2019 (Covid-19) yang menyerang organ pernapasan. Infeksi ini dilaporkan pada tanggal 31 Desember 2019 dalam bentuk gejala pneumonia dengan etiologi yang tidak diketahui dengan jelas penyebabnya di Kota Wuhan, Provinsi Hubei, Cina.

Identifikasi awal pada tanggal 9 januari 2020 menyatakan penyebab pneumonia ini adalah jenis baru virus corona dan diketahui Coronavirus merupakan bagian virus pernapasan yang menyebabkan penyakit pernapasan dan infeksi virus corona manusia lainnya (HCoV), termasuk HCoV 229E, NL63, OC43 dan HKU1 dapat menimbulkan penyakit saluran pernapasan dari yang ringgan seperti flu biasa hingga Middle East Respiratory Syndrome (MERSCoV) dan Severe Acute Respiratory Syndrome (SARS-CoV). Diagnosis Covid-19 didasarkan pada gejala dan paparan yang diketahui atau dari tes positif SARSCoV-2, meskipun dengan kondisi tanpa gejala, karena Covid-19 dapat menunjukkan gejala maupun tidak bergejala $^{(1),(2)}$.

Ibu hamil merupakan salah satu kelompok rawan penularan Covid-19. Namun, mayoritas ibu hamil yang terpapar Covid-19 tidak menunjukkan gejala. Gejala yang timbul pada umumnya hanya pilek/flu ringan atau sedang. Ibu hamil dengan Covid19 lbih kecil kemungkinan untuk mengalami demam atau myalgia dibandingkan yang tidak hamil pada usia yang sama. Namun upaya untuk mencegah penularan tetap harus dilakukan oleh Ibu hamil ${ }^{(2)}$.

Centers for Disease Control and Prevention (CDC) menyarankan agar ibu hamil dapat :

- Mempertimbangkan untuk mendapatkan vaksin Covid-19 bagi dirinya maupun keluarganya

- Membatasi interaksi langsung dengan orang-orang yang mungkin terpapar Covid-19, termasuk anggota keluarga sendiri

- Menggunakan masker di tempat umum pada saat berinteraksi dengan orang lain dan menghindari orang lain yang tidak menggunakan masker

- Menjaga jarak aman paling sedikit 1,5 meter dari orang lain

- Menghindari kerumunan dan ruangan yang berventilasi buruk

- Mencuci tangan menggunakan sabun atau pembersih berbasis alkohol

- Menghindari untuk menyentuh mata, hidung, dan mulut dengan tangan yang belum dicuci

- Pada saat batuk dan bersin gunakan tisu atau siku bagian dalam untuk menutup dan selanjutnya cucilah tangan

- Bersihkan permukaan benda yang sering disentuh menggunakan pembersih rumah tangga, seperti sabun dan deterjen

- Simpanlah setidaknya persediaan obat, baik yang diresepkan maupun yang tidak selama 30 hari $^{(3)}$.
Saran yang disampaikan oleh CDC dikenal di Indonesia dengan istilah Adaptasi Tatanan Kebiasaan Baru (AKB). Perubahan perilaku merupakan kunci dalam pelaksanaan AKB dengan mengupayakan agar hidup lebih bersih, sehat dan taat untuk melaksanakan protocol kesehatan ${ }^{(4)}$. Namun bagaimana penerapan AKB dan kondisi gizi pada ibu hamil di Kecamatan Sungailiat, Kabupaten Bangka, selama pandemi Covid-19 menjadi kajian dalam penelitian ini.

\section{METODE}

Penelitian ini merupakan penelitian deskriptif korelatif dengan desain potong lintang. Teknik pengambilan sampel dilakukan dengan metode consecutive sampling, yaitu ibu hamil yang melakukan pemeriksaan kehamilan di Puskesmas Sungailiat Kabupaten Bangka selama bulan September 2020. Analisis data dilakukan dalam bentuk analisa deskriptif dan analisa komparatif non parametrik.

\section{HASIL}

Berdasarkan pengumpulan data yang dilakukan pada 34 orang ibu yang melakukan pemeriksaan kehamilan di Puskemas Sungailiat selama bulan September 2020, maka diperoleh hasil sebagai berikut

1. Karakteristik Responden

Umur responden dikelompokkan dalam tiga kategori, yaitu kelompok umur di bawah 20 tahun, kelompok umur 20 - 35 tahun dan kelompok umur di atas 35 tahun. Kategori kelompok umur didasarkan pada risiko kehamilan menurut umur. Pada variabel ini diperoleh nilai mean sebesar 27,82, dan median 27 , serta modus 27 dalam rentang umur $20-42$ tahun.

Jumlah responden menurut kelompok umur diketahui sebagian besar berada dalam kelompok umur 20 - 35 tahun dan bertempat tinggal atau domisili di Kelurahan Sungailiat sebagaimana ditampilkan dalam gambar 1 .

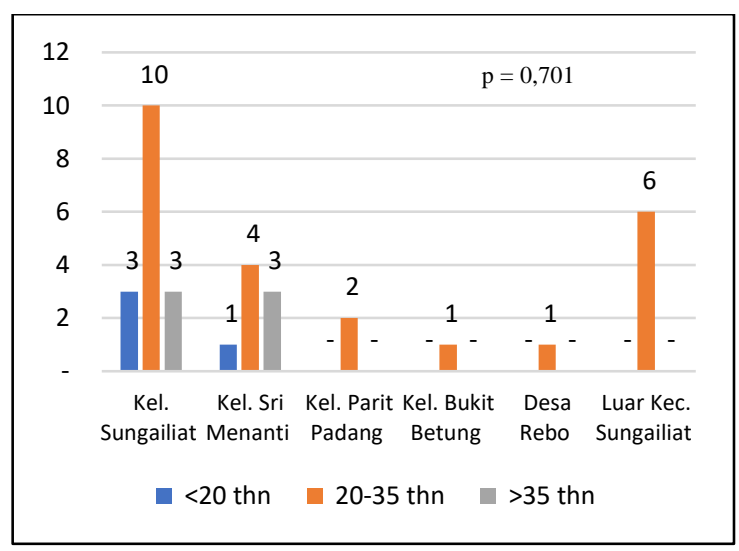

Gambar 1. Jumlah Responden menurut Domisili dan Kelompok Umur 


\section{Vol. 16 No.2 Mei - Agustus 2021}

Berdasarkan tingkat pendidikan, diketahui responden tersebar dalam berbagai tingkat pendidikan yang dikelompokkan menurut jenis pekerjaan disajikan dalam gambar 2. Sebagian besar responden mempunyai tingkat pendidikan SMA/sederajat dan bekerja sebagai ibu rumah tangga. Mereka yang tamat perguruan tinggi mempunyai jenis pekerjaan yang bervariasi.

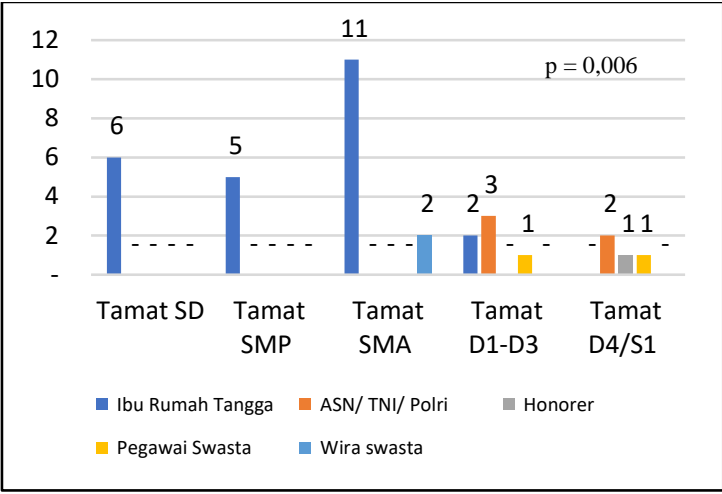

Gambar 2. Jumlah Responden menurut Tingkat Pendidikan dan Jenis Pekerjaan

\section{Kondisi Kehamilan}

Berdasarkan perhitungan usia kehamilan perhitungan menurut Hari Pertama Haid Terakhir (HPHT) terhadap responden dapat diketahui sebagian besar responden mempunyai usia kehamilan 25-39 minggu sebagaimana disajikan pada gambar 3 .

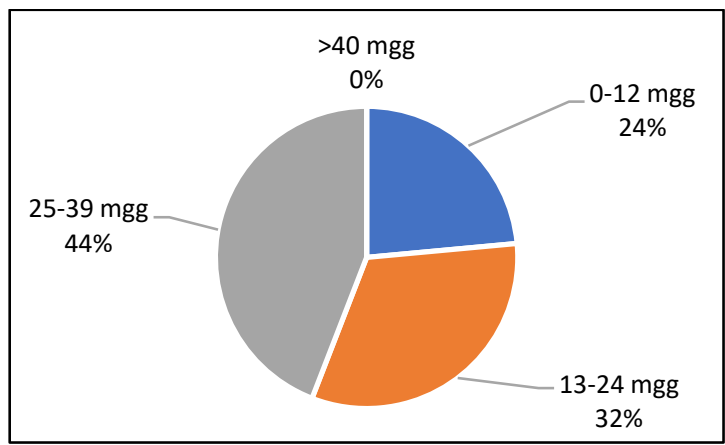

Gambar 3. Proporsi Jumlah Ibu Hamil menurut Usia Kehamilan

Sebagian besar responden pada saat diwawancarai dalam kondisi primigravida atau kehamilan pertama. Dalam penelitian ini, responden yang mempunyai kehamilan lebih dari tiga sebanyak $8,8 \%$ sebagaimana disajikan pada gambar 4 .

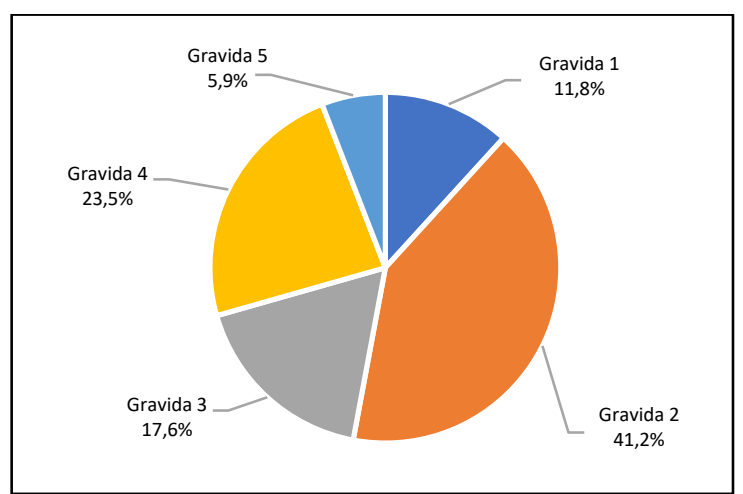

Gambar 4. Proporsi Ibu Hamil menurut gravida / Jumlah kehamilan

Riwayat kehamilan dengan abortus terdapat pada 3 orang atau $8,8 \%$ dan kelahiran dengan kondisi lahir mati dialami oleh 2 orang atau 5,9\% dari 34 responden yang ada.

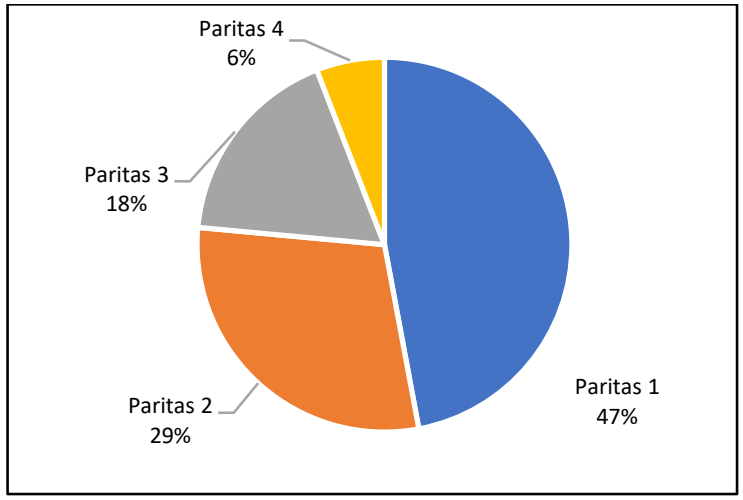

Gambar 5. Proporsi Ibu Hamil menurut Jumlah Melahirkan (Paritas)

\section{Adaptasi Tatanan Kebiasaan Baru Pada}

Responden

Adaptasi tatanan kebiasaan baru telah dilakukan sebagian responden, terutama terkait kebiasaan menggunakan masker, mencuci tangan pakai sabun menggunakan air mengalir dan menjaga jarak, namun kebiasaan untuk menghindari kerumunan masih belum dapat dilakukan sebagaimana terlihat pada gambar 6

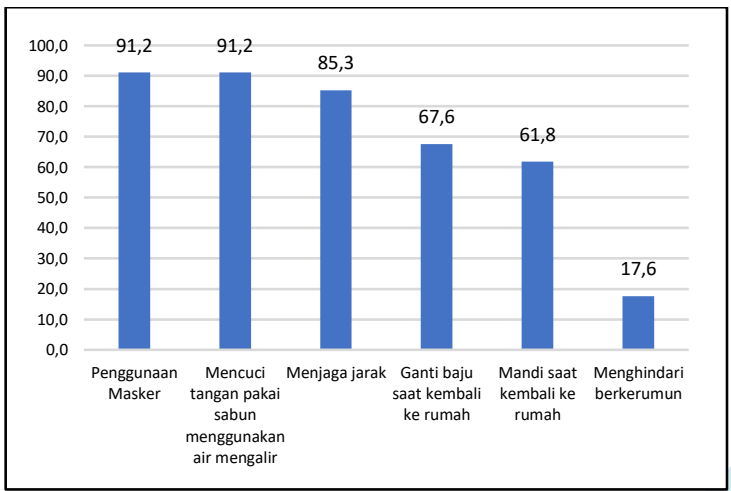


Gambar 6. Tingkat Kepatuhan Responden dalam melaksanakan Adaptasi Tatanan Kebiasaan Baru

Sebagian besar responden merasakan perbedaan dalam pelayanan kesehatan ibu hamil yang dirasakan pada saat pandemi bila dibandingkan dengan sebelum pandemi, sedangkan responden yang pada kondisi primigravida (kehamilan pertama) menyatakan raguragu atas pertanyaan tersebut sebagaimana ditampilkan pada gambar 7 .

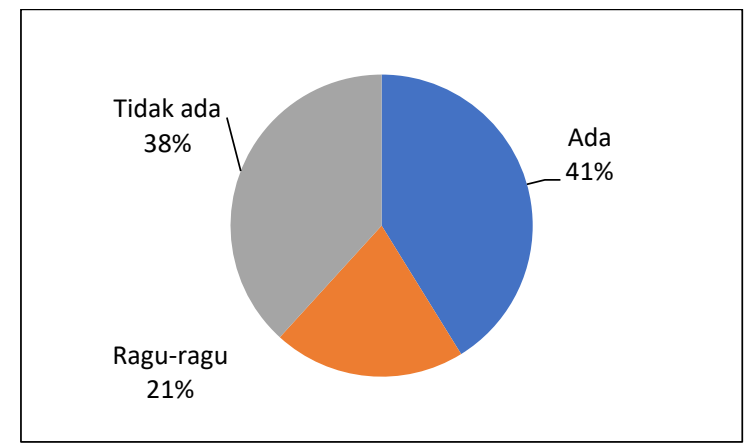

Gambar 7. Pendapat Responden tentang Adanya Perbedaan Pelayanan Kesehatan Ibu Hamil Sebelum dan Pada Saat Pandemi Covid-19

4. Pola Konsumsi Ibu Hamil selama Pandemi Covid-19

Sebagian besar responden telah membiasakan diri untuk mengkonsumsi makanan utama, namun masih sedikit responden yang membiasakan diri untuk mengkonsumsi makanan selingan seperti terlihat pada gambar 8 .

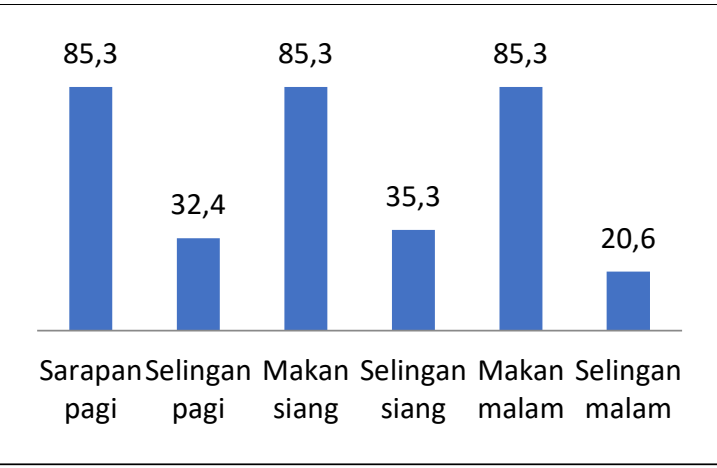

Gambar 8. Pola Konsumsi Ibu dalam Satu Hari

Berdasarkan hasil pemeriksaan kadar haemoglobin pada responden, diketahui sebagian besar responden tidak menderita anemia dengan batas kadar haemoglobin $(\mathrm{Hb})$ sebesar $11 \mathrm{gr} / \mathrm{dl}$. Kasus anemia terbanyak diderita oleh 6 orang $(17,5 \%)$ responden dengan kelompok umur 20 - 35 tahun sebagaimana ditampilkan dalam gambar 9. Pada variabel tingkat anemia responden diperoleh nilai mean sebesar 12,103, dan median 12,0 serta modus 12,0 dengan rentang kadar Hb 10,0 - 16,9 gr/dl.

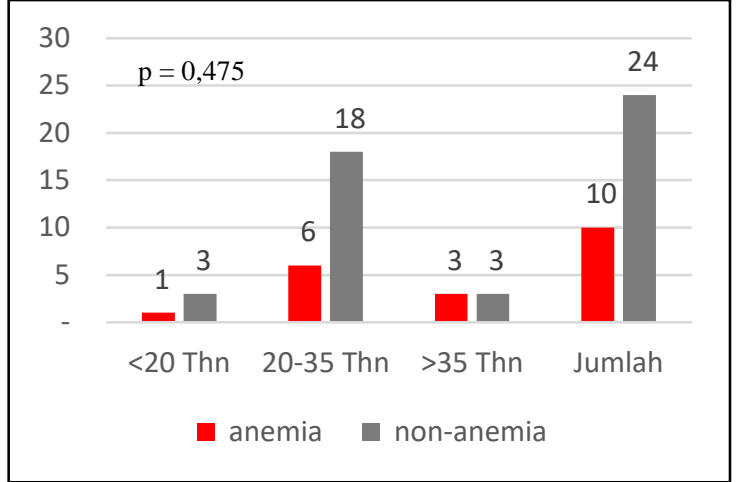

Gambar 9. Jumlah Responden yang berdasarkan Status Anemia dan Kelompok Umur

Pengukuran Lingkar Lengan Atas (LLA) guna penapisan masalah Kekurangan Energi Kronis (KEK) pada responden yang dilakukan, menunjukkan KEK dengan Batasan LILA sepanjang $23,5 \mathrm{~cm}$ hanya dialami oleh 3 orang $(8,8 \%)$ responden sebagaimana dirinci pada gambar 11 . Nilai mean pada variabel ini sebesar 26,294, dan median 26,0 serta modus 28,0 dengan rentang hasil pengukuran LLA $23,0-31,8 \mathrm{~cm}$.

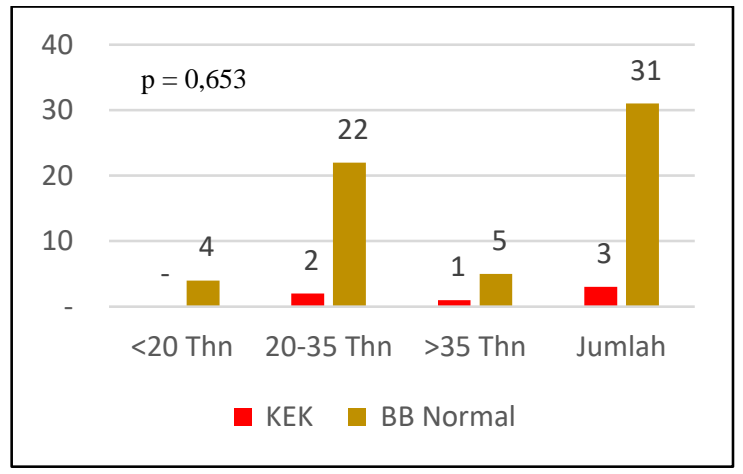

Gambar 10. Sebaran Responden menurut Status

Kekurangan Energi Kronis (KEK) dan Kelompok Umur

\section{PEMBAHASAN}

Pada sebagian besar kasus Covid-19 di tingkat global telah ditemukan bukti adanya penularan dari manusia ke manusia. Virus ini dapat diisolasi dengan mudah dari tetesan atau sekresi pernapasan, feses dan dari benda atau bahan yang kemungkinan besar membawa virus, seperti pakaian, perkakas dan furnitur. Penularan yang paling sering terjadi melalui kontak dekat dengan orang yang terinfeksi atau dari permukaan benda yang terkontamisasi. Meskipun jarang terjadi, penularan vertikal dari ibu ke bayinya sebelum lahir atau intrapartum dapat terjadi. Meskipun demikian, penularan tersebut tidak dipengaruhi oleh cara lahir, penjepitan tali pusat yang tertunda, kontak kulit ke kulit, metode, pemberian makan atau kondisi rawat gabung ${ }^{(2)}$. Walaupun risiko penularan masih ada selama kehamilan, namun belum ada penemuan virus 


\section{Vol. 16 No.2 Mei - Agustus 2021}

aktif dalam sampel cairan pada bayi yang dilahirkan atau air susu ibu (ASI) ${ }^{(5)}$.

Usia ibu pada saat hamil mempunyai pengaruh terhadap risiko kematian maternal dengan risiko 2-5 kali lebih tinggi pada ibu berusia di bawah 20 tahun bila dibandingkan dengan ibu pada usia 20-29 tahun dan risiko kematian kembali meningkat pada usia 3035 tahun $^{(6)}$.

Puskesmas Sungailiat mempunyai wilayah kerja meliputi tiga kelurahan di Kecamatan Sungailiat, yaitu Kelurahan Sungailiat, Kelurahan Sri Menanti dan Kelurahan Parit Padang dengan luas wilayah 14,14 km² dan jumlah penduduk sebanyak 46.239 jiwa $^{(7)}$.

Pada penelitian ini ditemukan sebanyak $11,8 \%$ ibu hamil dengan usia di bawah 20 tahun dan 17,6\% mempunyai usia di atas 35 tahun. Sebagian besar responden yang berdomisili di Kelurahan Sungailiat dan Sri Menanti berada pada kelompok umur 20-35 tahun dan hanya $12,5 \%$ yang mempunyai usia di bawah 20 tahun. Ibu hamil dengan kelompok umur di atas 35 tahun sebesar 37,5\% di Kelurahan Sri Menanti menunjukkan adanya risiko tinggi kehamilan yang cukup besar di Kelurahan tersebut. Namun tidak ada perbedaan yang bermakna antara jumlah ibu hamil menurut kelompok umur dengan domisili.

Ibu hamil dengan umur yang lebih tua, mempunyai kelebihan berat badan dan memiliki kondisi medis seperti hipertensi dan diabetes mempunyai risiko terkena Covid-19 yang lebih parah serta memerlukan perawatan lebih intensif. Kondisi ini dipengaruhi oleh dampak buruk yang mungkin akan dialami akibat beberapa infeksi saluran pernapasan yang terjadi, sehingga sangat penting agar ibu hamil dapat mencegah dan melindungi dari dari Covid-19 dan melaporkan setiap gejala yang mungkin seperti demam, batuk atau kesulitan bernapas kepada tenaga kesehatan $^{(1)}$.

Dalam penelitian ini ditemukan adanya hubungan bermakna antara tingkat pendidikan responden dengan jenis pekerjaan. Ibu hamil yang bekerja, kemungkinan besar akan lebih sering untuk pergi ke luar rumah dan berinteraksi dengan banyak orang, sehingga pemahaman terkait Covid-19 akan lebih baik. Namun interaksi tersebut juga dapat terjadi melalui media sosial atau media massa yang $\operatorname{ada}^{(8)}$. Meskipun demikian, dalam penelitian ini tidak ditelusuri lebih lanjut terkait dengan hubungan tingkat pendidikan atau pengetahuan pada ibu pekerja terhadap pemahaman tentang Covid-19.

\section{Adaptasi Kebiasaan Baru (AKB) pada Ibu hamil}

Pada penelitian ini ditemukan kebiasaan untuk menggunakan masker, mencuci tangan pakai sabun (CTPS) menggunakan air mengalir, dan menjaga jarak telah dilakukan oleh sebagian besar ibu hamil. Namun, belum semua ibu hamil yang membiasakan diri untuk mengganti baju dan mandi saat kembali ke rumah setelah bepergian. Upaya menghindari kerumunan juga masih sangat jarang dilakukan oleh ibu hamil dengan hanya $17,6 \%$ yang melakukan hal tersebut. Menghindari kerumunan merupakan salah satu hal yang penting dalam pencegahan Covid-19 agar jarak aman minimal 1,5 meter dapat dijaga.

Ibu hamil harus dapat melakukan pencegahan infeksi Covid-19 dengan cara melakukan :

- Selalu mencuci tangan menggunakan antiseptik berbasis alkohol atau sabun dengan air mengalir.

- Menjaga jarak dengan orang lain dan menghindari ruangan yang padat, sehingga jarak tetap dapat terjaga.

- Selalu menggunakan masker kain non-medis jika tidak memungkinkan untuk menjaga jarak fisik yang cukup dan hindari menyentuh mata, hidung dan mulut

- Selalu menjaga kebersihan pernapasan dengan menutup mulut dan hidung menggunakan siku atau tisu yang tertekuk saat batuk atau bersih.

- Segera dapatkan perawatan medis bila mengalami demam, batuk atau kesulitan bernapas.

- Ibu hamil dan ibu melahirkan agar selalu melakukan perawatan rutin dengan tenaga kesehatan serta mengikuti kebijakan lokal untuk mengurangi kemungkinan penularan Covid-19(5).

Pembentukan kebiasaan memerlukan waktu yang cukup lama yang memerlukan konseling perubahan perilaku yang sederhana dan berkelanjutan. Namun, tidak semua ibu hamil dapat menerima saran untuk mengubah perilakunya, sehingga tenaga kesehatan disarankan untuk memberikan panduan tentang perubahan perilaku dalam bentuk nasehat yang singkat, mudah diterapkan dan memiliki potensi dampak dalam jangka panjang secara realitis ${ }^{(9)}$.

Tanggapan individu terhadap situasi pandemi Covid-19 sangat beragam tergantung pada kemampuan individu yang bersangkutan untuk mempersepsikan dan mengolah informasi yang diterimanya. Informasi yang diterima akan diproses dalam otak untuk menghasilkan suatu respon kognitif dalam bentuk penilaian terhadap informasi tersebut ${ }^{(10)}$. Kondisi ini akan memberikan pengaruh kepada perilaku individu dalam melakukan adaptasi tatanan kebiasaan baru terkait Covid-19, termasuk pada ibu hamil.

Perilaku ibu dalam melakukan pencegahan terhadap penularan Covid-19 dapat dipengaruhi oleh keluarga, masyarakat dan media informasi yang ada ${ }^{(11)}$. Dukungan kepala keluarga sangat penting dalam pembentukan perilaku anggota keluarga, termasuk ibu hamil. Dukungan suami akan menjadi faktor penguat dari perilaku yang ada dengan memberikan penghargaan atau perangsang dan memberikan sumbangan terhadap kelangsungan dan pengulangan terhadap perilaku tersebut ${ }^{(12)}$.

Bentuk dukungan suami pada saat hamil dapat ditinjau dari berbagai dimensi, yaitu : 
- Dimensi Peran Domestik dengan peranan suami dalam membantu pekerjaan rumah tangga, mendampingi istri dan mengantar istri ke fasilitas kesehatan, serta menyediakan biaya untuk persalinan, menyediakan transportasi, dan dukungan emosional.

- Dimensi Peran Produktif dengan suami berperan dalam menyediakan sumber daya rumah tangga.

- Dimensi Peran Sosial/Kemasyarakatan, dengan suami berperan dalam mewujudkan kesejahteraan subjektif istri selama kehamilan hingga melahirkan $^{(13)}$.

Dukungan suami dan keluarga sangat dibutuhkan bagi ibu hamil, terutama di masa pandemi Covid-19. Kecemasan ibu hamil terkait kesiapan melahirkan dan belum adanya obat untuk penyakit akibat Covid-19 semakin meningkat, karena ibu khawatir terhadap terjadinya sesuatu yang tidak diinginkan $^{(14)}$.

Selain adanya dukungan dari suami dan keluarga kepada ibu hamil, termasuk dalam penciptaan perilaku yang mendukung adaptasi kebiasaan baru pada masa pandemi Covid-19, diperlukan juga upaya lain untuk meningkatkan pengetahuan ibu. Peningkatan pengetahuan ini sangat penting dilakukan, baik melalui metode penyuluhan maupun metode lainnya. Penyuluhan dalam bentuk ceramah memberikan pengaruh terhadap tingkat pengetahuan dan sikap ibu terkait adaptasi kebiasaan baru ${ }^{(15)}$.

Sebanyak $41 \%$ dari responden dalam penelitian ini menyatakan bahwa ada perbedaan antara pelayanan kesehatan yang dialaminya antara sebelum dan pada saat pandemi Covid-19. Responden yang menyatakan ada perbedaan mengungkapkan perbedaan yang dirasakan adalah kurang leluasanya responden pada saat berkunjung ke fasilitas pelayanan dibandingkan dengan sebelum pandemi terjadi. Pada saat pandemi, ibu diharapkan menggunakan masker, dan diminta untuk mencuci tangan sebelum memasuki fasilitas kesehatan serta diingatkan untuk selalu menjaga jarak dengan pengunjung lainnya.

\section{Konsumsi dan kondisi gizi ibu hamil}

Pada masa pandemi Covid-19, sebagian besar responden telah mengkonsumsi makanan utama sebanyak tiga kali dalam sehari. Namun, konsumsi makanan selingan masih sangat jarang dilakukan oleh responden. Sebagian besar responden menyatakan ada perbedaan antara konsumsi sebelum dan selama pandemi. Meskipun demikian, terdapat sebanyak $41,2 \%$ responden yang menyatakan tidak ada perbedaan. Perbedaan konsumsi yang dirasakan oleh responden antara lain meningkatnya porsi makan lebih banyak daripada konsumsi saat kehamilan sebelum pandemi,

Pandemi Covid-19 dapat menimbulkan kecemasan (ansietas), termasuk pada ibu hamil. Kecemasan akan mempengaruhi kondisi ibu, termasuk pola konsumsi ibu yang menyebabkan terjadinya gangguan napsu makan atau sebaliknya meningkatkan napsu makan. Perubahan pola makan ini akan berdampak pada imunitas ibu dalam mencegah paparan Covid-19 $19^{(16)}$

Efek pandemi terhadap tingkat kecemasan yang terjadi pada ibu hamil tidak sama antar individu. Pada umumnya, ibu akan lebih mudah mengalami perasaan cemas terhadap sesuatu yang akan terjadi kepada diri dan anaknya. Tidak adanya dukungan dari suami dan anggota keluarga lainnya serta tenaga kesehatan akan turut memberikan dampak pada peningkatan kecemasan tersebut ${ }^{(17)}$.

Secara umum, responden menyatakan tidak mempunyai makanan yang harus dipantang selama hamil pada masa pandemi, kecuali pada beberapa orang yang menyatakan perlu dilakukan untuk menghindari makan nenas, terong dan makanan yang dapat menimbulkan gas. Adanya makanan pantangan merupakan salah satu penyebab terjadinya masalah Kekurangan Energi Kronis (KEK) pada ibu hamil. Aspek lain yang mempengaruhi terjadinya KEK adalah tidak terbiasanya untuk makan bersama keluarga, makanan yang kurang beraneka ragam, kurangnya makan makanan sumber energi, baik secara frekuensi maupun jumlah, cara distribusi makanan yang kurang baik dengan mendahulukan ayah atau anak lelaki dibandingkan ibu hamil, dan pemilihan bahan makanan yang kurang baik ${ }^{(18)}$.

Berdasarkan hasil pengukuran Lingkar Lengan bagian Atas (LLA) diketahui hanya 8,8\% dari responden yang mengalami KEK dan hanya 20,6\% yang mengalami anemia. Pada masa kehamilan terjadi peningkatan kebutuhan energi dan zat gizi ibu hamil, namun kondisi ini sering tidak diiringi dengan jumlah konsumsi makanan yang cukup, terutama dari aspek kuantitas dan secara kualitas makanan ibu hamil sering kurang bervariasi, terutama pada makanan sumber karbohidrat, sumber protein dan sayuran serta buahbuahan $^{(19)}$. Pada penelitian ini sebagian besar responden mempunyai status gizi yang baik dengan hasil pengukuran LLA di atas $23,5 \mathrm{~cm}$.

Perubahan fisiologis dan mekanisme respon imun pada ibu hamil menyebabkan ibu rentan untuk mengalami gangguan kesehatan, termasuk gangguan yang disebabkan penyakit infeksi. Kondisi ini dapat mempengaruhi aliran zat gizi dan oksigen melalui plasenta yang berdampak pada perkembangan janin ${ }^{(20)}$.

Jumlah ibu hamil yang mengalami anemia dalam penelitian ini sebesar $20,6 \%$, sehingga bila diklasifikasikan menurut Badan Kesehatan Dunia (World Health Organization/WHO), maka kondisi ini termasuk dalam kategori kesehatan masyarakat tingkat moderat dengan prevalensi 20,0-39,9\%(21).

Asupan zat gizi dapat mempengaruhi sistem imun. Kekurangan zat besi sebagai salah satu zat gizi akan berdampak pada sistem kekebalan tubuh dengan mempengaruhi respon imun bawaan yang dapat meningkatkan risiko menderita penyakit infeksi. Efektivitas kerja jaringan sistem imun, seperti sel NK dan neutrofil akan mengalami hambatan, sehingga 


\section{Vol. 16 No.2 Mei - Agustus 2021}

infeksius yang masuk ke dalam tubuh tidak dapat dihancurkan ${ }^{(22)}$.

\section{KESIMPULAN}

Adaptasi Tatanan Kebiasaan Baru telah dilakuan dengan baik oleh sebagian besar ibu hamil dalam bentuk penggunaan masker, mencuci tangan pakai sabun (CTPS), dan menjaga jarak. Namun, ibu hamil belum membiasakan diri untuk selalu mengganti baju dan mandi segera setelah berpergian serta masih sangat jarang ibu hamil yang membiasakan diri untuk menghindari kerumunan. Ibu hamil sebagian besar menyatakan adanya perbedaan dalam pelayanan kesehatan di fasilitas kesehatan, karena kurang leluasanya ibu pada saat berkunjung ke fasilitas pelayanan dibandingkan dengan sebelum pandemi terjadi dan keharusan untuk menerapkan protokol kesehatan.

Pada masa pandemi Covid-19, sebagian besar ibu hamil telah mengkonsumsi makanan utama sebanyak tiga kali dalam sehari, tetapi konsumsi makanan selingan masih sangat jarang dilakukan. Ibu hamil merasakan adanya perbedaan antara konsumsi sebelum dan selama pandemic, sehingga mereka mengkonsumsi porsi makanan yang lebih banyak dibandingkan pada masa kehamilan di luar pandemi. Kecemasan merupakan salah satu factor yang diasumsikan mempengaruhi ibu hamil dalam mengkonsumsi makanan lebih banyak pada masa pandemi.

\section{DAFTAR PUSTAKA}

1. World Health Organization. WHO advice for international travel and trade in relation to the outbreak of pneumonia caused by a new coronavirus in China [Internet]. World Health Organization. 2020 [cited 2021 Apr 13].

Available from: https://www.who.int/newsroom/articles-detail/who-advice-forinternational-travel-and-trade-in-relation-to-theoutbreak-of-pneumonia-caused-by-a-newcoronavirus-in-china/

2. Royal College of Obstetricians and Gynaecologists. Coronavirus (COVID-19) Infection in Pregnancy [Internet]. London; 2021. Available from: https://www.rcog.org.uk/globalassets/documents /guidelines/2021-02-19-coronavirus-covid-19infection-in-pregnancy-v13.pdf

3. CDC. Pregnant and Recently Pregnant People. At increased risk for severe illness from COVID-19. [Internet]. Centers for Disease Control and Prevention (CDC). 2021 [cited 2021 Jun 12]. Available from: https://www.cdc.gov/coronavirus/2019- ncov/need-extra-precautions/pregnantpeople.html\#print

4. Pakar T. Adaptasi Kebiasaan Baru menuju Masyarakat Produktif dan Aman Covid-19 [Internet]. 2020. Available from: https://covid19.go.id/storage/app/media/Materi Edukasi/2020/Juni/Adaptasi Kebiasaan Baru menuju MPAC - 240620.pdf

5. World Health Organization. Coronavirus disease (COVID-19): Pregnancy and childbirth [Internet]. World Health Organization. 2020 [cited 2021 Apr 13]. Available from: https://www.who.int/news-room/q-adetail/coronavirus-disease-covid-19-pregnancyand-childbirth

6. Zakiah U, Fitri HN. Gambaran Kehamilan Remaja Ditinjau dari Umur, Penyebab Kehamilan dan Kontak Pertama dengan Tenaga Kesehatan di Wilayah Kerja Puskesmas Sikumana Kota Kupang. CHMK Midwifery Sci J [Internet]. 2020;3(1):128-33. Available from: http://cyber-

chmk.net/ojs/index.php/bidan/article/view/767/2 65

7. Bangka PK. Kecamatan Sungailiat [Internet]. Pemerintah Kabupaten Bangka. 2021 [cited 2021 Apr 13]. Available from:

https://www.bangka.go.id/?q=content/kecamatan -sungailiat

8. Purwoko M. Hubungan Tingkat Pendidikan dan Pekerjaan dengan Tingkat Pengetahuan Mengenai Kanker Ovarium pada Wanita. Mutiara Med J Kedokt dan Kesehat [Internet]. 2018;18(2):45-8. Available from: https://core.ac.uk/download/pdf/323996572.pdf

9. Gardner B, Lally P, Wardle J. Making health habitual: The psychology of "habit-formation" and general practice. Br J Gen Pract. 2012;62(605):664-6.

10. Agung IM. Memahami Pandemi COVID-19 dalam Perspektif Psikologi Sosial. Psikobuletin Bul Ilm Psikol [Internet]. 2020;1(2):68-84. Available from: http://ejournal.uinsuska.ac.id/index.php/Psikobuletin/article/view/9 616

11. Dewi R, Widowati R, Indrayani T. Pengetahuan dan Sikap Ibu Hamil Trimester III terhadap Pencegahan Covid-19. Heal Inf J Penelit. 2020;12(2):131-41.

12. Ora AT, Widjanarko B, Udijono A. Perilaku Ibu Rumah Tangga dalam Menggunakan Kelambu sebagai Upaya Pencegahan Malaria di Wilayah kerja Puskesmas Kabukarudi Kabupaten Sumba Barat Tahun 2014. J Promosi Kesehat Indones [Internet]. 2015;10(17-32). Available from: https://ejournal.undip.ac.id/index.php/jpki/article /view/18959/13223

13. Sudirman, Puspitawati H, Muflikhati I. Peran 
Suami dalam Menentukan Kesejahteraan

Subjektif Istri pada Saat Hamil dan Melahirkan.

J Ilmu Kel dan Konseling [Internet].

2019;12(1):26-37. Available from:

https://journal.ipb.ac.id/index.php/jikk/article/vie w/24190/16440

14. Angesti EPW. Hubungan Tingkat Kecemasan Dan Pengetahuan Ibu Hamil Trimester 3 Dengan Kesiapan Menghadapi Persalinan Di Masa Pandemi Covid-19 Di Puskesmas Benowo Dan Tenggilis [Internet]. Universitas Airlangga; 2020. Available from: http://repository.unair.ac.id/id/eprint/100606

15. Aditya R. Pengaruh Penyuluhan Tentang Adaptasi Kebiasaan Baru Bagi Ibu Hamil di Poliklinik Kebidanan RSUD Ulin Banjarmasin. In: Murwani E, editor. Prosiding Konferensi Nasional Pengabdian Kepada Masyarakat dan Corporate Social Responsibility [Internet]. Tangerang: Universitas Multimedia Nusantara; 2020. p. 270-3. Available from: http://prosidingpkmcsr.org/index.php/pkmcsr/article/view/734/4 66

16. Efrizal W. Persepsi dan Pola Konsumsi Remaja Selama Pandemi Covid-19. Ekotonia J Penelit Biol Bot Zool dan Mikrobiol [Internet]. 2020;05(2):43-8. Available from: https://journal.ubb.ac.id/index.php/ekotonia/artic le/view/2106/1351

17. Tantona MD. Gangguan Kecemasan pada Wanita Hamil di Saat Pandemi Covid-19. J Penelit Perawat Prof [Internet]. 2020;2(4):38192. Available from:

http://jurnal.globalhealthsciencegroup.com/index .php/JPPP

18. Muhamad Z, Hamalding H, Ahmad H. Analisis Kebiasaan Makan pada Ibu Hamil Kekurangan Energi Kronik di Wilayah Kerja Puskesmas Pulubala Kabupaten Gorontalo. J Komunitas Kesehat Masy [Internet]. 2019;1(1):48-57. Available from: https://uit.ejournal.id/JKKM/article/view/389/297

19. Abadi E, Putri LAR. Konsumsi Makronutrien pada Ibu Hamil Kekurangan Energi Kronik (KEK) di Masa Pandemi Covid-19. J Kesehat Manarang. 2020;6(2):85-90.

20. Rohmah MK, Nurdianto AR. Corona Virus Disease 2019 (Covid-19), Pada Wanita hamil dan Bayi : Sebuah Tinjauan Literatur. Medica Hosp J Clin Med. 2020;7(1A):329-36.

21. WHO. Haemoglobin concentrations for the diagnosis of anaemia and assessment of severity [Internet]. Geneva: World Health Organization; 2011. Available from: https://www.who.int/vmnis/indicators/haemoglo bin.pdf

22. Setyarsih L, Safitri I, Susanto H, Suhartono, Fitranti DY. Hubungan Tingkat Asupan Seng dan Zat Besi dengan Jumlah Leukosit Atlet Sepak Bola Remaja. J Nutr Coll [Internet].
2020;9(1):31-7. Available from: https://ejournal3.undip.ac.id/index.php/jnc/articl e/view/26926/23931 